\title{
Response of Chlorophyll and Nutrients Concentration in Leaves of Cape Gooseberry (Physalis peruviana L.) to Integrated Nutrient Management
}

\author{
Akhilendra Verma ${ }^{1 *}$, S.P. Singh ${ }^{1}$, Rajiv Kumar Singh ${ }^{2}$ and Bijendra Kumar Singh ${ }^{1}$ \\ ${ }^{1}$ Department of Horticulture, Institute of Agricultural Sciences Banaras Hindu University, \\ Varanasi- 221005 (U.P.), India \\ ${ }^{2}$ Krishi Vigyan Kendra, Soahan Ballia (U.P.), India \\ *Corresponding author
}

\section{A B S T R A C T}

\begin{tabular}{|l|}
\hline K e y w o r d s \\
Cape gooseberry, \\
Chlorophyll, \\
Nutrient, Integrated \\
nutrient \\
management.
\end{tabular}

\section{Introduction}

The Cape gooseberry (Physalis peruviana L.) belongs to the family Solanaceae commonly known as rasbhari in India. It is tetraploid and hexaploid $(2 \mathrm{n}=4 \times=48$ and $2 \mathrm{n}=6 \times=72)$ in nature. The genus Physalis includes about 100 species characterized by fruits that bear an inflated calyx (Legge, 1974). Integrated nutrient management includes the use of inorganic, organic and microbial sources of nutrients which ensure balanced nutrient proportion by enhancing nutrient response efficiency and maximizing crop productivity of desired quality. It also helps in minimizing the existing gap between the nutrient removal through continuous use of chemical fertilizers and supply through slow release of fertilizers. It is well reported that the extensive use of chemical fertilizers adversely affect the soil health and results in decreased crop productivity and quality (Macit et al., 2007). Thus, in this experiment an attempt has been made to assess the response of chlorophyll and nutrients concentration in cape gooseberry leaves (Physalis peruviana L.) to integrated nutrient management.

\section{Materials and Methods}

The present investigation was carried out during winter season of 2013-14 and 2014-15 
at the Vegetable Research Farm, Institute of Agricultural Sciences, Banaras Hindu University, Varanasi. The treatment comprised with different doses of NPK@ 100,80 and $60 \mathrm{~kg} \mathrm{ha}^{-1}$, farm yard manure @ 15 tonne ha ${ }^{-1}$ along with bio-fertilizers (Azotobacter and phosphorus solubilising bacteria) @ 50mL in 20 litres of water according to the treatment combination. The design of the experiment was randomized block design with three replications and fifteen treatments viz., T1- 50\% NPK, $\mathrm{T}_{2}$ $50 \% \mathrm{NPK}+\mathrm{FYM}, \mathrm{T}_{3}-50 \% \mathrm{NPK}+\mathrm{FYM}+$ $\mathrm{AZB}, \mathrm{T}_{4}-50 \% \mathrm{NPK}+\mathrm{FYM}+\mathrm{PSB}, \mathrm{T}_{5}-50 \%$ $\mathrm{NPK}+\mathrm{FYM}+\mathrm{AZB}+\mathrm{PSB}, \mathrm{T}_{6}-75 \% \mathrm{NPK}$, $\mathrm{T}_{7}-75 \% \mathrm{NPK}+\mathrm{FYM}, \mathrm{T}_{8}-75 \% \mathrm{NPK}+\mathrm{FYM}$ $+\mathrm{AZB}, \mathrm{T}_{9}-75 \% \mathrm{NPK}+\mathrm{FYM}+\mathrm{PSB}, \mathrm{T}_{10}-$ $75 \% \mathrm{NPK}+\mathrm{FYM}+\mathrm{AZB}+\mathrm{PSB}, \mathrm{T}_{11}-100 \%$ NPK, $\mathrm{T}_{12}-100 \%$ NPK + FYM, $\mathrm{T}_{13}-100 \%$ $\mathrm{NPK}+\mathrm{FYM}+\mathrm{AZB}, \mathrm{T}_{14}-100 \% \mathrm{NPK}+\mathrm{FYM}$ + PSB and $\mathrm{T}_{15}-100 \% \mathrm{NPK}+\mathrm{FYM}+\mathrm{AZB}+$ PSB.

The required quantity of organic manures as per treatment combination was applied at the time of land preparation. Urea was applied in two split doses before planting and flowering stages while the full doze of phosphorus and potash was given before planting. Azotobactor and phosphorus solubilising bacteria solutions were made by dissolving $50 \mathrm{~mL}$ in 20 litres of water. The roots of cape gooseberry seedlings having 4-5 full open leaves were thoroughly dipped in the solution for about $30 \mathrm{~min}$. and then planted on beds at $50 \mathrm{~cm} \times 50 \mathrm{~cm}$ distance with the help of khurpi on $10^{\text {th }}$ September of 2013 and 2014, respectively. Other cultural practices like weeding, hoeing, irrigation, insect pest and disease management were done as and when required. Observation on total chlorophyll concentration was measured by chlorophyll meter and value was read as (SPAD reading) just before flower bud formation. For a meaningful plant analysis, care should be taken during sampling. In cape gooseberry plant, fully expanded matured leaves without petiole were selected for sampling (Bhargava and Raghupati, 1993).

Total nitrogen was estimated by the microKjeldhl method as per procedure suggested by AOAC (1990). The estimation of $\mathrm{N}$ through the micro-Kjeldahl method consisted of three processes, viz., digestion, distillation and titration.

The phosphorus content was estimated from digestion of acid with a spectrophotometer using the procedure of Bhargava and Raghupati (1984).

The potassium content was estimated from digestion of acid with flame photometer using procedure as described by Bhargava and Raghupati (1984).

\section{Results and Discussion}

Accumulation of nutrient in plant tissue indicates the accessibility of the concerned nutrients from the soil to the plant. In plant, nutrient exists in good relationship between the concentration of nutrients in the plant and the total biomass of the plant.

A correct nutrient in the plant tissues is closely associated with maximum yield, except in the case of luxury consumption of nutrients like potassium. Significant error may arise in the plant analysis due to wrong sampling therefore selecting the right plant part, stages of growth and time of sampling are very crucial in plant analysis.

The plant nutrient content was influenced significantly by the various treatment combinations. Maximum nitrogen content was reported in $100 \% \mathrm{NPK}+\mathrm{FYM}+\mathrm{AZB}+$ PSB treated plants followed by $100 \%$ NPK + $\mathrm{FYM}+\mathrm{AZB}$ and $75 \% \mathrm{NPK}+\mathrm{FYM}+\mathrm{AZB}+$ PSB treatment, whereas the minimum nitrogen content was noted in 50\% NPK treated plants (Table 1). 
Table.1 Effect of integrated nutrient management on nitrogen, phosphorus, potassium and chlorophyll content in cape gooseberry leaves (mean of 2 year)

\begin{tabular}{|c|c|c|c|c|c|c|c|c|c|c|c|c|}
\hline \multirow{2}{*}{ Name of treatments } & \multicolumn{3}{|c|}{ Nitrogen content $(\%)$. } & \multicolumn{3}{|c|}{ Phosphorus content (\%). } & \multicolumn{3}{|c|}{$\begin{array}{l}\text { Potassium content } \\
\qquad(\%) .\end{array}$} & \multicolumn{3}{|c|}{$\begin{array}{c}\text { Chlorophyll (SPAD } \\
\text { reading). }\end{array}$} \\
\hline & $\begin{array}{c}2013- \\
14\end{array}$ & $\begin{array}{c}2014- \\
15\end{array}$ & Pooled & $\begin{array}{c}2013- \\
14\end{array}$ & $\begin{array}{c}2014- \\
15\end{array}$ & Pooled & $\begin{array}{c}2013- \\
14\end{array}$ & $\begin{array}{c}2014- \\
15\end{array}$ & $\begin{array}{l}\text { Pool } \\
\text { ed }\end{array}$ & $\begin{array}{c}2013 \\
-14\end{array}$ & $\begin{array}{c}2014- \\
15\end{array}$ & Pooled \\
\hline $\mathrm{T}_{1}(50 \% \mathrm{NPK})$ & 1.67 & 1.70 & 1.68 & 0.503 & 0.520 & 0.512 & 1.42 & 1.44 & 1.43 & 17.07 & 17.05 & 17.06 \\
\hline $\mathrm{T}_{2}(50 \% \mathrm{NPK}+\mathrm{FYM})$ & 1.93 & 1.93 & 1.93 & 0.573 & 0.577 & 0.575 & 1.75 & 1.76 & 1.76 & 17.80 & 17.82 & 17.81 \\
\hline $\mathrm{T}_{3}(50 \% \mathrm{NPK}+\mathrm{FYM}+\mathrm{AZB})$ & 2.73 & 2.74 & 2.74 & 0.590 & 0.603 & 0.597 & 1.82 & 1.82 & 1.82 & 17.43 & 17.45 & 17.44 \\
\hline $\mathrm{T}_{4}(50 \% \mathrm{NPK}+\mathrm{FYM}+\mathrm{PSB})$ & 2.33 & 2.36 & 2.34 & 0.743 & 0.740 & 0.742 & 2.33 & 2.35 & 2.34 & 21.57 & 21.58 & 21.57 \\
\hline $\mathrm{T}_{5}(50 \% \mathrm{NPK}+\mathrm{FYM}+\mathrm{AZB}+\mathrm{PSB})$ & 3.44 & 3.46 & 3.45 & 0.853 & 0.870 & 0.862 & 2.83 & 2.83 & 2.83 & 16.27 & 16.27 & 16.27 \\
\hline $\mathrm{T}_{6}(75 \% \mathrm{NPK})$ & 2.03 & 2.00 & 2.02 & 0.650 & 0.657 & 0.653 & 1.97 & 1.98 & 1.98 & 17.07 & 17.07 & 17.07 \\
\hline $\mathrm{T}_{7}(75 \% \mathrm{NPK}+\mathrm{FYM})$ & 3.03 & 3.01 & 3.02 & 0.807 & 0.813 & 0.810 & 2.50 & 2.53 & 2.52 & 18.73 & 18.73 & 18.73 \\
\hline $\mathrm{T}_{8}(75 \% \mathrm{NPK}+\mathrm{FYM}+\mathrm{AZB})$ & 4.15 & 4.17 & 4.16 & 0.897 & 0.893 & 0.895 & 2.93 & 2.96 & 2.95 & 17.83 & 17.35 & 17.59 \\
\hline $\mathrm{T}_{9}(75 \% \mathrm{NPK}+\mathrm{FYM}+\mathrm{PSB})$ & 3.79 & 3.83 & 3.81 & 1.030 & 1.060 & 1.045 & 3.15 & 3.17 & 3.16 & 18.60 & 18.65 & 18.62 \\
\hline $\mathrm{T}_{10}(75 \% \mathrm{NPK}+\mathrm{FYM}+\mathrm{AZB}+\mathrm{PSB})$ & 4.33 & 4.43 & 4.38 & 1.113 & 1.147 & 1.130 & 3.32 & 3.34 & 3.33 & 17.03 & 17.05 & 17.04 \\
\hline $\mathrm{T}_{11}(100 \% \mathrm{NPK})$ & 2.67 & 2.67 & 2.67 & 0.747 & 0.747 & 0.747 & 2.16 & 2.15 & 2.16 & 18.30 & 18.32 & 18.31 \\
\hline $\mathrm{T}_{12}(100 \% \mathrm{NPK}+\mathrm{FYM})$ & 3.30 & 3.33 & 3.32 & 0.833 & 0.837 & 0.835 & 2.63 & 2.63 & 2.63 & 14.23 & 14.24 & 14.24 \\
\hline $\mathrm{T}_{13}(100 \% \mathrm{NPK}+\mathrm{FYM}+\mathrm{AZB})$ & 4.74 & 4.80 & 4.77 & 0.950 & 0.953 & 0.952 & 3.03 & 3.15 & 3.09 & 16.00 & 16.05 & 16.03 \\
\hline $\mathrm{T}_{14}(100 \% \mathrm{NPK}+\mathrm{FYM}+\mathrm{PSB})$ & 3.97 & 3.98 & 3.98 & 1.233 & 1.240 & 1.237 & 3.52 & 3.57 & 3.54 & 19.13 & 19.18 & 19.16 \\
\hline $\mathrm{T}_{15}(100 \% \mathrm{NPK}+\mathrm{FYM}+\mathrm{AZB}+\mathrm{PSB})$ & 4.86 & 4.92 & 4.89 & 1.323 & 1.337 & 1.330 & 3.60 & 3.64 & 3.62 & 19.03 & 19.25 & 19.14 \\
\hline $\mathrm{CD}(\mathrm{P}=0.05)$ & 0.18 & 0.17 & 0.17 & 0.125 & 0.100 & 0.113 & 0.16 & 0.13 & 0.15 & 1.55 & 0.18 & 0.87 \\
\hline
\end{tabular}


Similar results were also obtained by Ranjit and Bandyopadhyay (2014) in tomato, Singh and Singh (2009) in strawberry.

Increased plant nutrient content might be due to the biological nitrogen fixation and production of enzyme complex, which solubilize the unavailable form of nutrient elements and render them available (Marwaha, 1995).

Higher phosphorus content of leaves was reported in $100 \%$ NPK + FYM + AZB + PSB treated plants. This increase may be explained owing to organic acids production by plants and bacteria in the rhizosphere, which in turn stimulates the availability of $\mathrm{P}, \mathrm{Fe}$ and $\mathrm{Zn}$. These findings corroborate the results of Smith and Read, 199, Shen et al., 2004.

Phosphorus is an essential nutrient for plant growth and development and is one of the most important elements in crop production. Despite its wide distribution in nature, it is a deficient nutrient in most of soils, especially in soils which have a high phosphorus fixation capacity. Phosphate solubilizing microorganisms render these insoluble phosphates into soluble form through the process of acidification, chelatiation and exchange reactions (Banik and Dey, 1981; Bhattacharya et al., 1986).

Increase in phosphorus uptake with the increase in application of nitrogen has been reported by Yadav (2010) in peach. Higher potassium content in cape gooseberry leaf was reported in 100\% NPK + FYM + AZB + PSB treated plants followed by $100 \%$ NPK + FYM + PSB treatment, whereas it was the minimum in 50\% NPK treated plant. These results are in agreement with findings of Babaet al., (2010) in strawberry, Shashi et al., (2011) in aonla.

Maximum chlorophyll concentration was recorded in 50\% NPK + FYM + PSB treated plants followed by $100 \%$ NPK + FYM + PSB treated plants. Similar results were also reported by Wang and Lin (2002) and Singh and Singh (2009) in strawberry.

Increased chlorophyll may be attributed because of increased biological nitrogen fixation, better organic nitrogen utilization, better development of root system and enhanced synthesis of plant growth regulators like IAA, $\mathrm{GA}_{3}$ and cytokinin (Martinez et al., 2001).

From the results it may be concluded that the integrated use of nutrients was better than their alone application. Treatment $100 \%$ NPK $+\mathrm{FYM}+\mathrm{AZB}+\mathrm{PSB}$ performed better in respect of nitrogen, phosphorus and potassium whereas where as $50 \%$ NPK + FYM + PSB better in respect of Chlorophyll content.

\section{References}

A.O.A.C., Official methods of analysis, Association of Official Analytical Chemists. $15^{\text {th }}$ ed. Washington, D.C, USA, 1990.

Baba, Z. A., Zargar, M. Y. and Mir, S. A. Effect of inorganic and biofertilizers on soil physico chemical properties and micronutrient availibility in strawberry (Fragaria $\times$ ananassa Duch.).Asian Journal.ofSoil Sciences., 5(1): 90-93, 2010.

Banik, S., and Dey, B.K., Phosphate solubilizing microorganisms isolated from Bihar soils. Solubilisation of inorganic phosphate and production of organic acids by microorganisms isolated in sucrose calcium phosphate agar plates. Zentralblatt fur Bakteriologie, 136: 478-486, 1981.

Bhargava, B. S., and Raghupathi, H. B. Analysis of plant materials for macroand micro-nutrients. Pp.49-82. in: H.L.S. Tandon (ed.), Methods of 
Analysis of Soils, Plants, Waters and Fertilizers. Fertilizer Development and Consultation Organization, 1984.

Bhargava, B. S., and Raghupati, H. B.Analysis of plant materials for macro and micronutrients. In: H.L.S. Tandon (Ed.). Methods of Analysis of Soil, Plants, Water and Fertilizers, p. 49-82. FDCO, New Delhi, 1993.

Bhattacharya, P., Dey, B.K., Banik, S., Nath, S., Organic manures in relation to rhizosphere effect. Effect of organic manures on phosphate solubilizing power of rice and successing wheat rhizosphere soils. Zentralblatt fur Microbiologie, 141: 357-365, 1986.

Legge, A.P., 1974. Notes on the history, cultivation and uses of Physalis peruviana L. Journal of the Royal Horticulture Society 99(7), 310-314.

Macit, I., Koc, A., Guler, S. and Deligoz, I. 2007. Yield, quality and nutritional status of organically and conventionally grown strawberry cultivars. Asian Journal of Plant Science 6(7): 11311136.

Martinez, R., Dibut, B., Casanova, I. and Ortega, M. Stimulating action of Azotobacter chroococcum on tomato crop on a red ferrallitic soil. Agrotecnia-de-Cuba, 27: 23-26, 2001.

Marwaha, B. C., Biofertilizers- A supplementary source of plant nutrient. Fert. News, 40: 39-50, 1995.

Ranjit, C., and Bandyopadhyay, S. Studies on effect of organic, inorganic and biofertilizers on plant nutrient status and availability of major nutrients in tomato.Inter. J. of Bio-resource and Stress Management, 5 (1): 93-97, 2014.

Shashi, B., Chaudhary, V. R. and Shukla, H. S. Effect of organic manure and biofertilizers with graded dose of NPK on soil and leaf nutrient status of Aonla (EmblicaofficinalisGaertn.) cv. Banarasi. Karnataka J. Agric. Sci., 24(5): 709-711, 2011.

Shen, J., Li, R., Zhang, F., Fan, J., Tang, C. and Rengel, Z., Crop yields, soil fertility and phosphorus fractions in response to long term fertilization under rice monoculture system on a calcareous soil. Field Crop Res., 86: 225-238, 2004.

Singh, A., and Singh, J. N. Effect of biofertilizers and bioregulators on growth, yield and nutrient status of strawberry cv. Sweet Charlie. Indian Journal of Horticulture, 66 (2): 220224, 2009.

Smith, S. E., and Read, D. Mycorrhizal Symbiosis. Academic Press, San Diego. Soil Survey Staff, 1992. Keys to Soil Taxonomy, $5^{\text {th }}$ edition, 1997.

Wang, S. Y., and Lin, S. S. Composts as soil supplement enhanced plant growth and fruit quality of strawberry. J. of Plant Nutrition, 25(10): 2243-2259, 2002.

Yadav, S., Integrated nutrient management studies in subtropical peach cv. Saharanpur prabhat under high density system. Ph.D. Thesis, C.S.A. U.A.T., Kanpur, India, 2010.

\section{How to cite this article:}

Akhilendra Verma, S.P. Singh, Rajiv Kumar Singh and Bijendra Kumar Singh. 2017. Response of Chlorophyll and Nutrients Concentration in Leaves of Cape Gooseberry (Physalis peruviana L.) To Integrated Nutrient Management. Int.J.Curr.Microbiol.App.Sci. 6(9): 2647-2651. doi: https://doi.org/10.20546/ijcmas.2017.609.326 